Article

\title{
Exploitation of Liquid Digestate as the Sole Nutrient Source for Floating Hydroponic Cultivation of Baby Lettuce (Lactuca sativa) in Greenhouses
}

\author{
Georgios K. Ntinas ${ }^{1}\left(\mathbb{D}\right.$, Filippos Bantis ${ }^{2} \mathbb{D}$, Athanasios Koukounaras ${ }^{2}\left(\mathbb{D}\right.$ ) and Panagiotis G. Kougias ${ }^{3, *}$ \\ 1 Institute of Plant Breeding and Genetic Resources, Hellenic Agricultural Organization-Dimitra, \\ 57001 Thessaloniki, Greece; gntinas@ipgrb.gr \\ 2 Department of Horticulture, School of Agriculture, Aristotle University of Thessaloniki, \\ 54124 Thessaloniki, Greece; fbantis@agro.auth.gr (F.B.); thankou@agro.auth.gr (A.K.) \\ 3 Soil and Water Resources Institute, Hellenic Agricultural Organization-Dimitra, 57001 Thessaloniki, Greece \\ * Correspondence: p.kougias@swri.gr
}

check for

updates

Citation: Ntinas, G.K.; Bantis, F.; Koukounaras, A.; Kougias, P.G.

Exploitation of Liquid Digestate as the Sole Nutrient Source for Floating Hydroponic Cultivation of Baby

Lettuce (Lactuca sativa) in

Greenhouses. Energies 2021, 14, 7199. https://doi.org/10.3390/en14217199

Academic Editors:

Panagiotis Tsapekos and

Merlin Alvarado-Morales

Received: 7 October 2021

Accepted: 28 October 2021

Published: 2 November 2021

Publisher's Note: MDPI stays neutral with regard to jurisdictional claims in published maps and institutional affiliations.

Copyright: (c) 2021 by the authors. Licensee MDPI, Basel, Switzerland. This article is an open access article distributed under the terms and conditions of the Creative Commons Attribution (CC BY) license (https:/ / creativecommons.org/licenses/by/ $4.0 /)$.

\begin{abstract}
Sustainable agriculture relies on replacing fossil-based mineral fertilizers, which are highly cost-energetic to produce, and demand extensive use of scarce natural resources. Today, agronomic practices within the concept of circular economy are emerging and, as such, the exploitation of digestate as a biofertilizer and soil amender is extensively investigated. This study aimed at evaluating the agronomic potential of liquid digestate as the sole nutrient source for hydroponic cultivation of baby lettuce in greenhouses. Growth rate, physiological responses, concentration of secondary metabolites, and nutrient uptake were compared between baby leaf lettuce grown in digestate in concentrations of 5,10 , and $20 \%$ diluted in water (either with or without $\mathrm{pH}$ adjustment) and in Hoagland solution (control). Results showed that the production yield was negatively correlated with the concentration of the added digestate. Nevertheless, the antioxidant capacity was significantly enhanced in 5 and $10 \%$ liquid digestate treatments compared to the control. Additionally, the nutrient composition in the baby leaf lettuce and the reduction in nutrient concentrations in the growth media demonstrated efficient mineral uptake by the plants. Thus, the application of liquid digestate as a fertilizer in hydroponic systems is a promising practice to recover residual resources, leading to the transition towards more sustainable greenhouse production.
\end{abstract}

Keywords: greenhouse; biogas plant; liquid digestate; nutrient uptake; sustainability; residual resource recovery; secondary metabolites

\section{Introduction}

Anaerobic digestion is a widely applied process for the valorization of organic residues, with simultaneous production of green energy (i.e., biogas) $[1,2]$. However, after the anaerobic decomposition of influent feedstocks, large quantities of digestate (i.e., welldigested effluent) are generated. Digestate is a semisolid material that is rich in both organic matter and in macro- and micronutrients, including nitrogen $(\mathrm{N})$, phosphorus $(\mathrm{P})$, potassium (K), and sulfur (S) [3]. Thus, the concentration of such elements in the digestate offers unique opportunities for its exploitation as a plant biofertilizer. However, the physicochemical characteristics of digestate may vary significantly from one biogas plant to another, due to the different nature and composition of the influent feedstock, and due to specific operational parameters of the overall process (e.g., operational temperature of the reactor). For example, biogas plants that treat agricultural/livestock byproducts (e.g., manure or silages) generate digestate that contains a high solid fraction due to the fibrous recalcitrant material. On the other hand, a more liquid digestate is the outcome of biogas reactors processing agro-industrial wastewater.

Typically, digestate follows a solid-liquid separation to fractionate the different phases of the effluent. The separated solid fraction is better appreciated due to several advan- 
tages related to its handling and utilization, such as simpler storage, considerably lower transportation costs, and transformation into biofertilizers via drying or composting $[4,5]$. However, the main portion deriving from the separation - and most problematic in terms of management-is the liquid fraction. It has been previously reported that part of the liquid fraction can be recirculated to the biogas reactor to avoid the use of water for dilution of substrates with high solid contents, and to reduce substrate consumption [6]. For the remaining part, there are a variety of nutrient recovery and treatment options, relying on different levels of technological readiness. The simplest solution is to be used for "fertigation" - a process combining fertilization and irrigation, in which the liquid digestate is spread onto the fields. However, direct application of liquid digestate in soils may lead to detrimental environmental impacts, such as volatilization of ammonia and nutrients, leading to eutrophication and chemical, biological, and physical contamination, causing severe damage to soil properties $[7,8]$. Thus, more efficient and sustainable solutions for the utilization of the increasing quantities of liquid digestate need to be identified in order to meet the demands of the continuous proliferation of biogas plants globally.

Hydroponic cultivation offers numerous advantages, such as efficient use of natural resources (i.e., water, energy, soil, etc.), less intensive labor, and maximization of the crop's yield and quality due to the controlled environmental conditions. Traditionally, in most hydroponic systems, the crops are planted into specific substrates that can be organic (e.g., peat, coconut fiber, bark, wood fiber, etc.), inorganic (e.g., rockwool, pumice, sand, perlite, vermiculite, expanded clay), or synthetic (e.g., polyurethane, polystyrene) [9]. Even though these substrates can provide homogeneous water/nutrient supply and maintain uniform EC and $\mathrm{pH}$ levels through the entire substrate slab, they present some critical environmental impacts related to their fate upon their disposal to final recipients at the end of cultivation. Indeed, the organic substrates that can be incorporated to the soil may contain pesticides or other harmful soil contaminants, while the inorganic substrates are subjected to incineration — which is an expensive process—or are disposed to landfills, causing soil, water, and aesthetic pollution.

For the above reasons, floating hydroponic systems are gaining increased attention today for the production of leafy vegetables. Floating systems are among the most simple, convenient, and low-cost hydroponic methods used for the production of high-quality baby leaf vegetables $[10,11]$. Moreover, when applying floating hydroponic techniques, the end products are cleaner, without substrate traces [12]. In turn, this is beneficial for post-harvest washing and storage processes. Here, the optimization of nutrient solution management can potentially reduce the amounts of nitrates and oxalic acid [13]. Hoagland solution [14] is widely used by producers due to the easy control of the nutrient solution's consistency.

Lettuce (Lactuca sativa L.) is one the most popular vegetables worldwide, and is mainly consumed in the form of fresh leaves. The crop can be cultivated throughout the year due to a vast selection of cultivars with variable climate resilience; it can also be grown in greenhouses fitted with cooling systems. Lettuce leaves have relatively low protein and carbohydrate contents, while they are rich in $\beta$-carotene, ascorbic acid, calcium, phosphorus, and iron [15].

Nitrates are noxious, possibly carcinogenic compounds with regards to human healthparticularly for infants [16]. The main sources of nitrate and nitrite consumption are leafy vegetables, which tend to accumulate higher amounts in their leaves rather than their roots, seeds, and stems [17], while sunlight is known to negatively affect nitrate concentration. Along with lettuce, popular leafy vegetables such as rocket and spinach are known for their high nitrate accumulation [17]. For example, lettuce leaves have a typical nitrate concentration of $2500 \mathrm{mg} / \mathrm{kg}$ fresh weight, while the respective amount for asparagus is only $13 \mathrm{mg} / \mathrm{kg}$.

Currently, limited information is available on the efficacy of digestate as a nutrient source for hydroponic cultivation in greenhouses. Stoknes et al. [18] reported that the liquid fraction of digestate can serve as a mineral-based fertilizer in commercial substrates for short-cycle crops (e.g., lettuce, herbs). Moreover, Ronga et al. [19] concluded that digestate, 
as a growing medium, demonstrated higher quality indices for basil and peppermint cultivation compared to the treatment in which the crop was grown on a solid substrate (agriperlite). In a more recent study, Ronga et al. [20] outlined that digestate can be a sustainable alternative growth medium or nutrient solution for baby leaf lettuce cultivation in hydroponic systems. Nevertheless, all of the above works emphasize solid and liquid digestate-based crop cultivation. Hence, there is a lack of scientific findings regarding the exploitation of the liquid fraction of digestate as a nutrient source in floating hydroponic systems, thus excluding the necessity of growing plants on solid substrates.

The present study is a pioneer in elucidating the feasibility of vegetable cultivation (baby leaf lettuce) in floating hydroponic systems using digestate as the sole nutrient source for the plant growth. Different levels of digestate dilution into water were evaluated in terms of crop production yield and quality. The examined treatments were additionally compared with cultivation using Hoagland nutrient solution. The outcomes of the current work are of major importance for improving the current state-of-the-art agronomic practices, and for developing sustainable greenhouse production in the era of circular economy.

\section{Materials and Methods}

\subsection{Greenhouse Set Up and Plant Material}

Lettuce (Lactuca sativa L.) cv. Parris Island Cos was cultivated in a heated glass pitchedroof greenhouse in the facilities of the Hellenic Agricultural Organization-DIMITRA, Thermi, Thessaloniki, Greece. The plants were grown in the period of December to January, in a floating system up to the baby leaf stage. The critical air temperature point for heating the greenhouse was set at $14^{\circ} \mathrm{C}$. The cultivation trays were not heated.

The greenhouse air temperature and humidity as well as the baby leaf root zone temperature were recorded and stored using a programmable logic controller (PLC) installed in the greenhouse. The solar radiation and the photosynthetic active radiation entering the greenhouse were also recorded. An external meteorological station in front of the greenhouse was used to measure the external climatic conditions.

The seeds were sown in polystyrene mini-plug trays filled with peat, at a density of 1149 seedlings $/ \mathrm{m}^{2}$. Upon cotyledon emergence, the mini-plug trays were placed in polystyrene tanks $(550 \times 340 \times 186 \mathrm{~mm})$ filled with nutrient solution.

\subsection{Liquid Digestate}

Digestate was obtained from Lagadas Biogas Plant (Lagadas, Greece), which is a full-scale biogas plant co-digesting livestock manure and other agricultural residues. Upon arrival to the laboratory facilities, the digestate was filtered once with a $1 \mathrm{~mm}$ mesh to remove solid particles. The liquid digestate was homogenized and subsequently stored at $-20{ }^{\circ} \mathrm{C}$ for further usage. Triplicate samples were obtained to determine the nutrient composition of the liquid digestate (Table 1).

\subsection{Nutrient Solution}

The control tanks were filled with 100\%-strength Hoagland nutrient solution ( $\mathrm{pH}$ 6.5). The rest of the nutrient solutions consisted of water derived from a borehole of the Hellenic Agricultural Organization-DIMITRA campus (Thermi, Greece), along with 5, 10, or $20 \%$ digestate, with or without $\mathrm{pH}$ adjustment. The rationale for the $\mathrm{pH}$ adjustment was attributed to the fact that the liquid digestate had a higher $\mathrm{pH}$ value compared to the Hoagland nutrient solution, which corresponds to the range for optimal cultivation. Average $\mathrm{pH}$ and electrical conductivity (EC) for each nutrient solution during the experimental period are presented in Table 2. Each nutrient solution/treatment consisted of three tanks/repetitions. 
Table 1. Nutrient composition of the liquid digestate used in the experiment.

\begin{tabular}{cc}
\hline Parameter Concentration & Value (mg/L) \\
\hline $\mathrm{N}$ & $331.33 \pm 47.65$ \\
$\mathrm{P}$ & $153.62 \pm 12.89$ \\
$\mathrm{~K}$ & $470.25 \pm 2.05$ \\
$\mathrm{Ca}$ & $12.90 \pm 3.25$ \\
$\mathrm{Mg}$ & $3.38 \pm 0.31$ \\
$\mathrm{Na}$ & $106.20 \pm 1.13$ \\
$\mathrm{Cd}$ & $0.01 \pm 0.00$ \\
$\mathrm{Co}$ & $0.04 \pm 0.02$ \\
$\mathrm{Cr}$ & $0.05 \pm 0.01$ \\
$\mathrm{Ni}$ & $0.28 \pm 0.01$ \\
$\mathrm{~Pb}$ & $<0.042$ \\
$\mathrm{Mn}$ & $0.02 \pm 0.00$ \\
$\mathrm{Fe}$ & $4.20 \pm 1.56$ \\
$\mathrm{Zn}$ & $2.42 \pm 0.10$ \\
$\mathrm{Cu}$ & $0.40 \pm 0.10$ \\
\hline
\end{tabular}

Table 2. Average $\mathrm{pH}$ and EC for each nutrient solution during the experimental period.

\begin{tabular}{ccc}
\hline Nutrient Solution & $\mathbf{p H}$ & EC $(\mathbf{m S} / \mathbf{c m})$ \\
\hline $100 \%$ Hoagland (Control) & $6.4-7.0$ & $2.67-2.75$ \\
$5 \%$ digestate & $7.7-8.0$ & $2.46-2.79$ \\
$5 \%$ digestate (adj. $\mathrm{pH})$ & $6.7-7.5$ & $2.59-2.73$ \\
$10 \%$ digestate & $7.7-8.1$ & $3.85-4.06$ \\
$10 \%$ digestate $($ adj. $\mathrm{pH})$ & $6.7-7.6$ & $4.05-4.38$ \\
$20 \%$ digestate & $8.0-8.3$ & $6.54-7.00$ \\
$20 \%$ digestate $($ adj. $\mathrm{pH})$ & $6.7-7.9$ & $6.88-7.33$ \\
\hline
\end{tabular}

\subsection{Harvest and Analytical Measurements}

One day prior to harvest, leaf net photosynthetic rate $\left(\mu \mathrm{mol} \mathrm{CO} 2 / \mathrm{m}^{2} \mathrm{~s}^{1}\right)$, stomatal conductance $\left(\mathrm{mol} / \mathrm{m}^{2} \mathrm{~s}^{1}\right)$, and transpiration rate $\left(\mathrm{mmol} / \mathrm{m}^{2} \mathrm{~s}^{1}\right)$ were measured, from 11:00 to 13:00, using an infrared gas analyzer (LCi-SD portable photosynthesis system, ADC BioScientific Ltd., Hoddesdon, UK). Leaves were harvested when they reached a commercial size of $10-12 \mathrm{~cm}$ length after 27 days of cultivation. Upon yield determination, the leaves were stored in a freezer $\left(-30^{\circ} \mathrm{C}\right)$ until phytochemical analyses. Subsequently, the leaves were homogenized, and their soluble sugar content was immediately determined using a digital refractometer (PAL- $\alpha$, Atago, Tokyo, Japan).

Nitrate content was determined after extraction with deionized water according to the method described by Cataldo et al. [21]. Aliquots containing $0.2 \mathrm{~mL}$ of extract were added to $0.8 \mathrm{~mL}$ of $\mathrm{H}_{2} \mathrm{SO}_{4}$ and $0.8 \mathrm{~mL}$ of $5 \%$ salicylic acid- $\mathrm{H}_{2} \mathrm{SO}_{4}$ solution, followed by addition of $19 \mathrm{~mL}$ of $2 \mathrm{MN} \mathrm{NaOH}$ after $20 \mathrm{~min}$. Absorbance was measured with a spectrophotometer at $410 \mathrm{~nm}$.

Total phenolic content was determined after extraction with 80\% methanol according to the Folin-Ciocalteu method described by Singleton and Rossi [22]. According to this method, $0.5 \mathrm{~mL}$ of extract was added to $2.5 \mathrm{~mL}$ of $10 \%$ Folin-Ciocalteu reagent and $2 \mathrm{~mL}$ of $7.5 \% \mathrm{Na}_{2} \mathrm{CO}_{3}$, followed by $5 \mathrm{~min}$ incubation at $50{ }^{\circ} \mathrm{C}$. Absorbance was measured with a spectrophotometer at $760 \mathrm{~nm}$.

Antioxidant capacity was determined after extraction with $80 \%$ methanol according to the ferric-reducing antioxidant potential (FRAP) method, as described by Benzie and Strain [23]. According to the method, $0.1 \mathrm{~mL}$ of extract was added to $3 \mathrm{~mL}$ of working solution composed of $\mathrm{CH}_{3} \mathrm{COONa}$, TPTZ, and $\mathrm{FeCl}_{3}$, followed by 4 min of incubation at $37^{\circ} \mathrm{C}$. Absorbance was immediately measured with a spectrophotometer at $593 \mathrm{~nm}$.

The experimental design was randomized complete block design (RCBD), consisting of three replications per treatment. Analysis of variance was conducted with IBM SPSS 
software (SPSS 25.0, IBM Corp., Armonk, NY, USA), and comparisons of the means were conducted using Tukey's method at the significance level $\alpha=0.05$.

For nutrient analyses, available phosphorus $(\mathrm{P})$ was determined according to the Olsen method [24], while the concentrations of $\mathrm{K}, \mathrm{Ca}, \mathrm{Mg}, \mathrm{Na}, \mathrm{Cd}, \mathrm{Co}, \mathrm{Cr}, \mathrm{Ni}, \mathrm{Pb}, \mathrm{Mn}, \mathrm{Fe}$, $\mathrm{Zn}$, and $\mathrm{Cu}$ were measured as described in [25].

\subsection{Statistical Analysis}

Results are presented as the mean value of three replicates together with the standard deviation. Determination of statistically significant differences was performed by using Student's $t$-test and one-way ANOVA analysis (Tukey's test) for the comparison of values within single or multiple experimental treatments, respectively. Differences with a $p$-value $<0.05$ were considered significant. Statistical analyses were performed using SPSS 25.0.

\section{Results and Discussion}

\subsection{Microclimatic Conditions in the Greenhouse and Root Zone Temperature}

Heating was applied in the greenhouse to retain the minimum air temperature inside the greenhouse at $\sim 14{ }^{\circ} \mathrm{C}$, except for a limited number of nights during which there was a problem with the heat pump (Figure 1a). Even though external temperature was often near or below $0{ }^{\circ} \mathrm{C}$ during nighttime, the greenhouse conditions were favorable for leaf and root zone temperatures (Figure 1b). The solar radiation recorded inside the greenhouse was significantly lower compared to the incident radiation to the greenhouse, due to the diffuse glass cover (Figure 1c). However, it was possible to increase the air temperature inside the greenhouse up to $30^{\circ} \mathrm{C}$ or more, since no ventilation was applied. Water temperature inside the trays was more uniform-especially after the first two days, following which there was a much lower range in the air temperature of the greenhouse.

\subsection{Quantitative Characteristics of Baby Leaf Lettuce}

The $\mathrm{pH}$ in the trays containing the Hoagland nutrient solution (control) was 6.35 and 6.71 at the beginning and the end of the experiment, respectively, while its value ranged from 6.35 to 6.99 during the cultivation (Figure $2 \mathrm{a}$ ). In the trays with $5 \%$ digestate, the $\mathrm{pH}$ was 8.03 at the beginning of the cultivation period, and it dropped to 7.8 by the end of the cultivation, while during the cultivation the $\mathrm{pH}$ value ranged from 7.65 to 8.03 (Figure 2a). In the trays with 5\% digestate in which the $\mathrm{pH}$ had been adjusted, the value at the beginning of the cultivation was 6.69, and at the end it was equal to 7.45 , while during the experiment the range of $\mathrm{pH}$ values fluctuated between 6.69 and 7.45 . In the trays with $10 \%$ digestate, $\mathrm{pH}$ was 8.07 at the beginning of the crop and 8.00 at the end; during the cultivation, $\mathrm{pH}$ values ranged from 7.68 to 8.07 (Figure $2 \mathrm{a}$ ). In the trays with $10 \%$ digestate in which $\mathrm{pH}$ was adjusted, at the beginning of the experiment its value was 6.69 , while at the end it was 7.57; during the cultivation period, the $\mathrm{pH}$ ranged from 6.69 to 7.57 . In the trays containing $20 \%$ digestate, the $\mathrm{pH}$ at the beginning of the experiment was 8.11 , while at the end it was 8.29, with a range during the cultivation from 7.99 to 8.29 . In the trays with $20 \%$ digestate and adjusted $\mathrm{pH}$, the $\mathrm{pH}$ was 6.81 at the beginning of the experiment and reached 7.88 by the end, while its values during the cultivation ranged from 6.81 to 7.88 . 


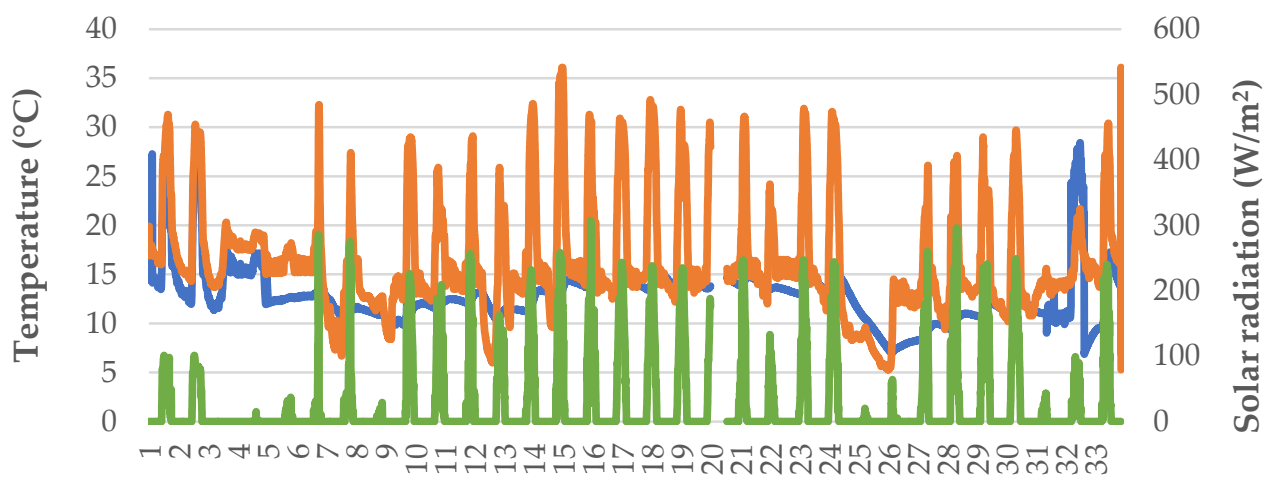

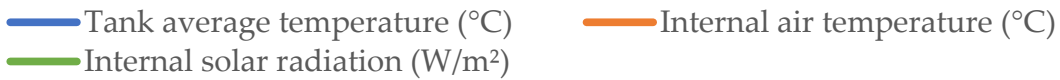

(a)

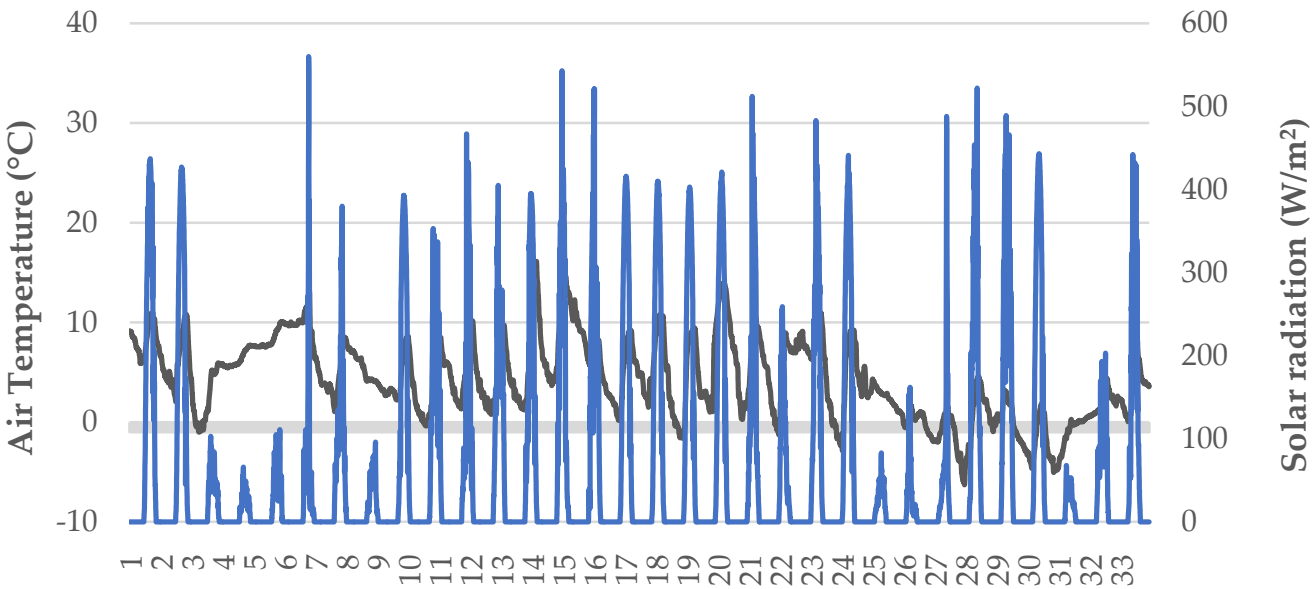

External air temperature $\left({ }^{\circ} \mathrm{C}\right) \quad$ External solar radiation $\left(\mathrm{W} / \mathrm{m}^{2}\right)$

(b)

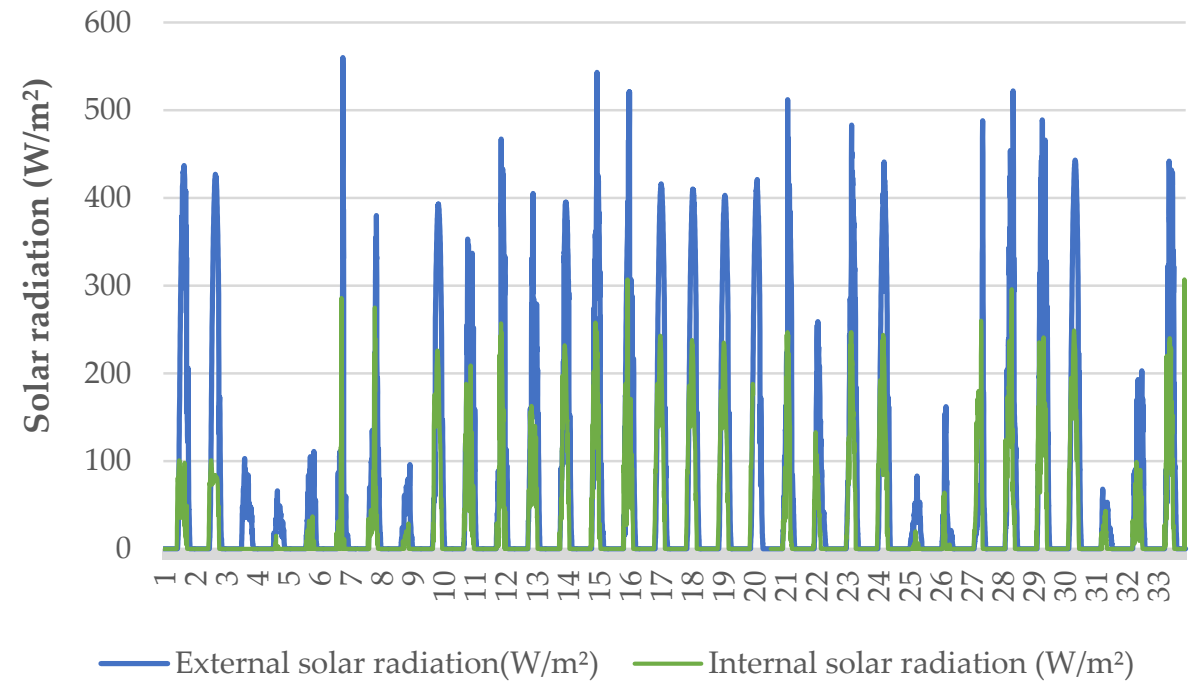

(c)

Figure 1. Microclimatic data (a), external weather conditions (b), and solar radiation (c) during the cultivation period. 


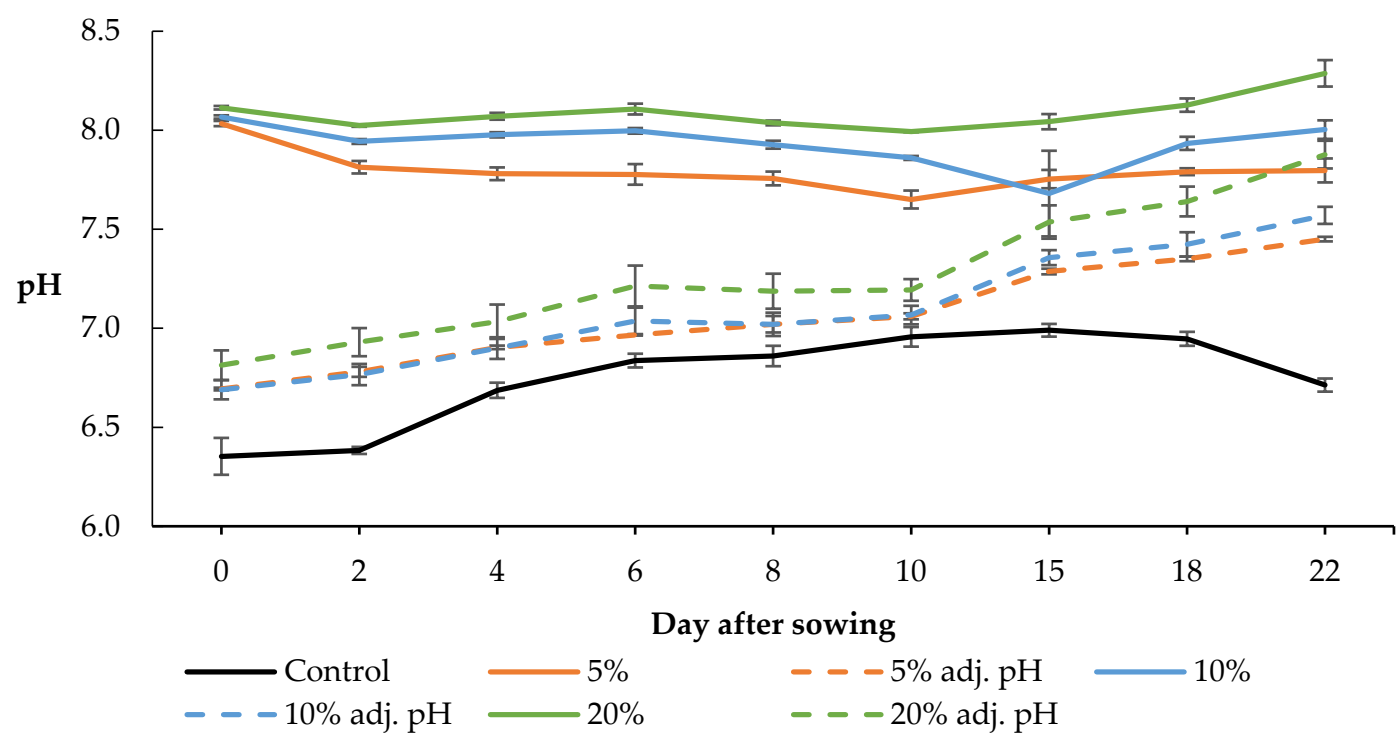

(a)

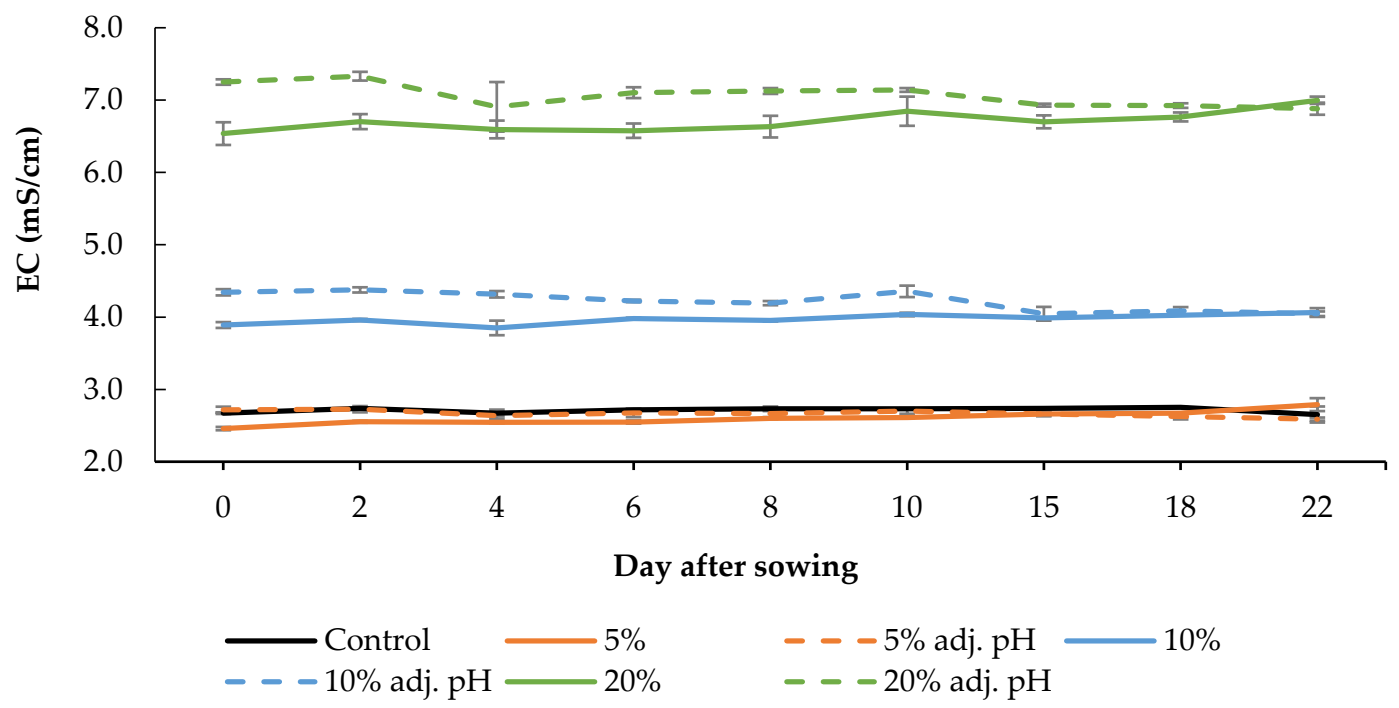

(b)

Figure 2. $\mathrm{pH}$ (a) and electrical conductivity (EC) (b) of different digestate solutions during the cultivation period. Data presented are mean values \pm standard error $(p<0.05)$.

We observed that the $\mathrm{pH}$ values in the treatments with the adjusted $\mathrm{pH}$ continued to increase after the middle of the cultivation period, even though they had an initial value close to that of the control treatment. Conversely, the $\mathrm{pH}$ values of the control were found to decrease in the same period. Treatments that did not receive $\mathrm{pH}$ correction had a significantly higher $\mathrm{pH}$ than the control at the beginning of the growing season. In trays with 5 and $10 \%$ digestate, the $\mathrm{pH}$ was lower at the end of the cultivation period than at the beginning, while in trays with $20 \%$ digestate the corresponding value was found to be increased. The increase in the $\mathrm{pH}$ of the growing media of lettuce grown in a floating system was also observed in a previous study, and was attributed to the $\mathrm{NO}_{3}-\mathrm{N}$ absorption [26]. It is well known that baby lettuce accumulates nitrate in its leaves; thus, proper monitoring of nitrogen sources in hydroponic cultivations should be considered in order to improve their nutritional quality [27].

It was observed that electrical conductivity (EC) was mainly affected by the concentration of digestate for the various treatments. In trays with $5 \%$ digestate, with and without 
adjusted $\mathrm{pH}, \mathrm{EC}$ was within the same limits as the control. In contrast, significant variations were recorded by comparing the EC values of the trays with $10 \%$ and $20 \%$ digestate with those of the control treatment. Particularly, the treatments with adjusted $\mathrm{pH}$ presented an even greater difference at the beginning of the growing season.

Yield was significantly affected by the nutrient source. Specifically, the control led to the highest obtained yield compared to all liquid digestate treatments, while the latter followed a negative gradient from 5 to $20 \%$ liquid digestate. In particular, $5 \%$ with or without $\mathrm{pH}$ adjustment showed significantly greater yield compared to the non-adjusted $10 \%$ and both $20 \%$ treatments, while both $10 \%$ treatments showed greater yield compared to both $20 \%$ treatments (Figure 3). Our results are consistent with those of a previous study by Celletti et al. [28], who found greater shoot and root fresh weight in maize seedlings produced with a nutrient solution compared to liquid cow manure digestate. It should be noted that the digestate used in the experiment was obtained after the obligatory pasteurization process of the biogas plant. Therefore, potential microbial impacts on root development and plant stimulation were not considered in this study.

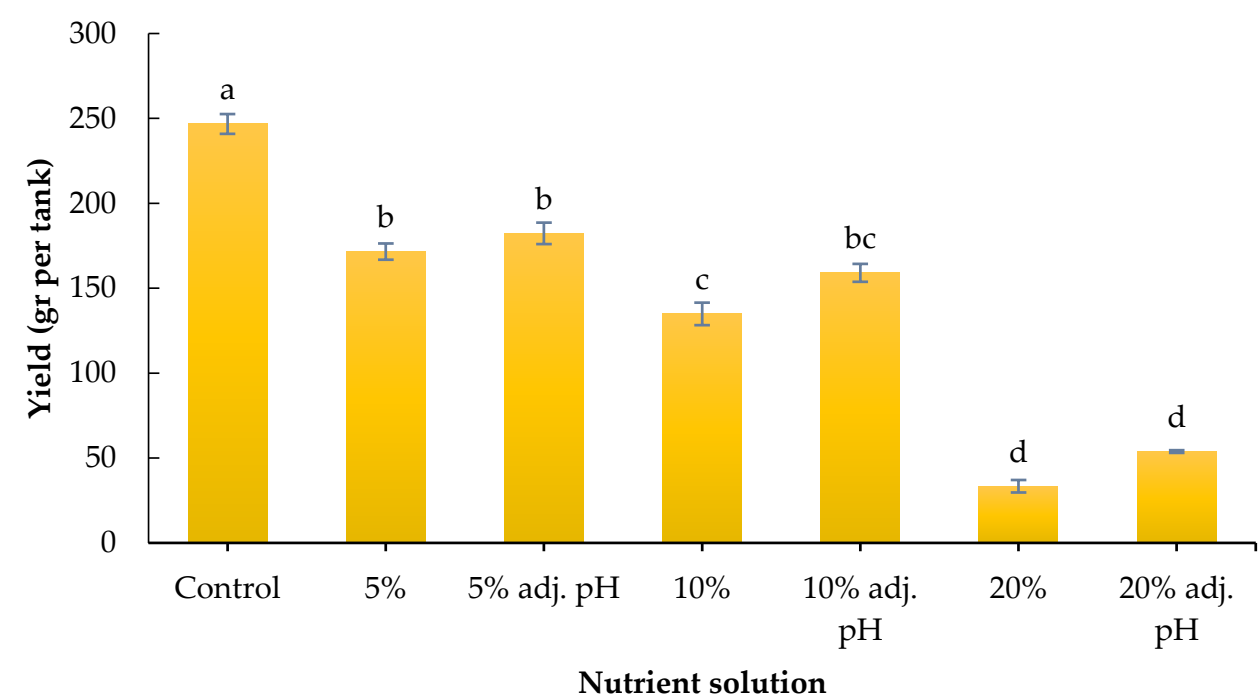

Figure 3. Yield (gr/tank) of baby lettuce grown under different digestate solutions. Columns (means $\pm \mathrm{SE}$ ) with different letters are significantly different $(p<0.05)$.

Photosynthetic active radiation (PAR) was measured on the leaf surface. The control treatment and $10 \%$ liquid digestate also presented significantly lower values compared to the other treatments, probably due to momentary roof structure or curtain shadowing (Figure 4a). Transpiration rate values were similar in both 5 and $10 \%$ liquid digestate treatments, and significantly higher than control and both $20 \%$ liquid digestate treatments for baby lettuce (Figure 4b). Slightly higher transpiration rates were reported by Karnoutsos et al. [11] for non-heated cultivation in Hoagland solution during the winter season. Stomatal conductance did not show any significant difference in baby lettuce plants except for the treatment with $20 \%$ liquid digestate, with or without $\mathrm{pH}$ adjustment (Figure $4 \mathrm{c}$ ). Baby leaf lettuce had the highest net photosynthetic rate value in $10 \%$ liquid digestate treatment, with a statistically significant difference compared to all other treatments. The lowest value was measured in the treatment with $20 \%$ digestate without $\mathrm{pH}$ adjustment (Figure 4d). 


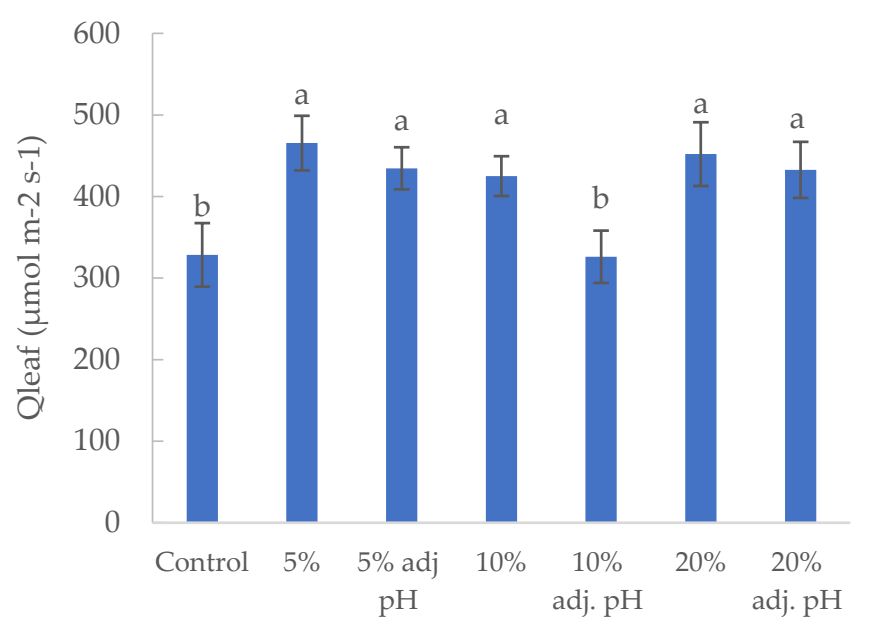

(a)

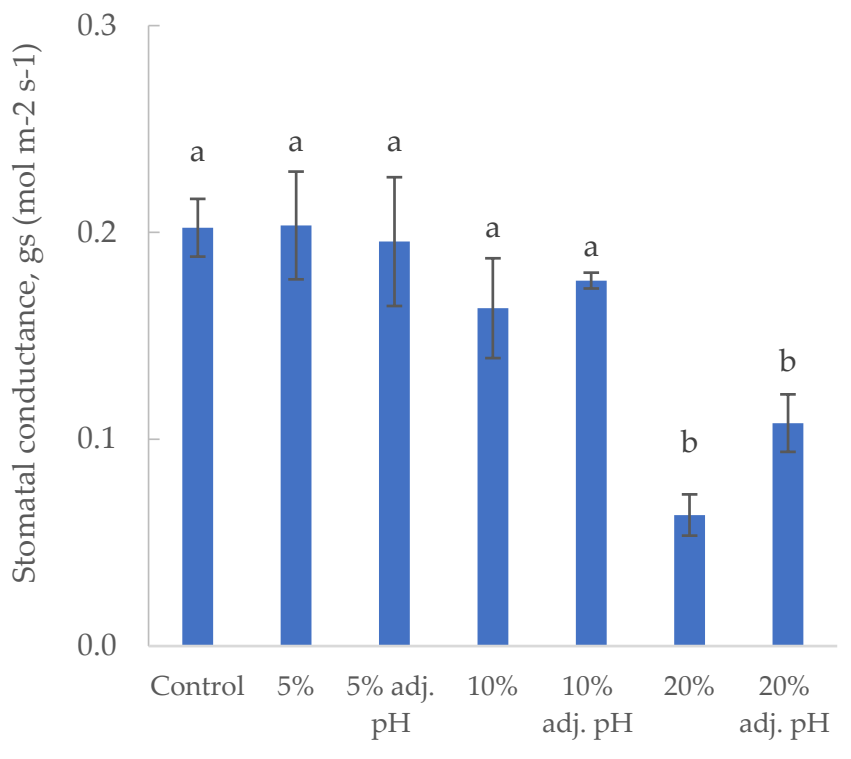

(c)

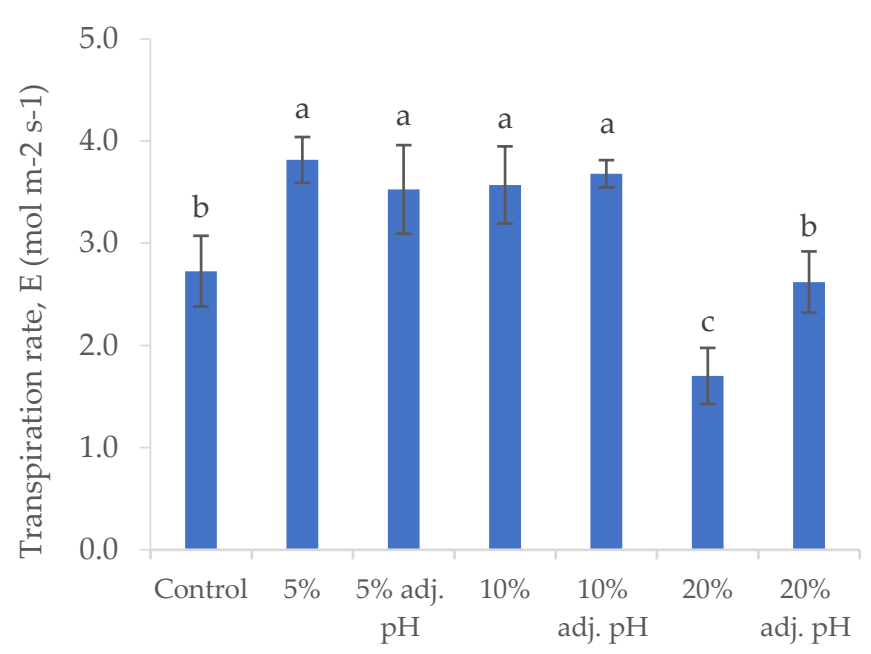

(b)

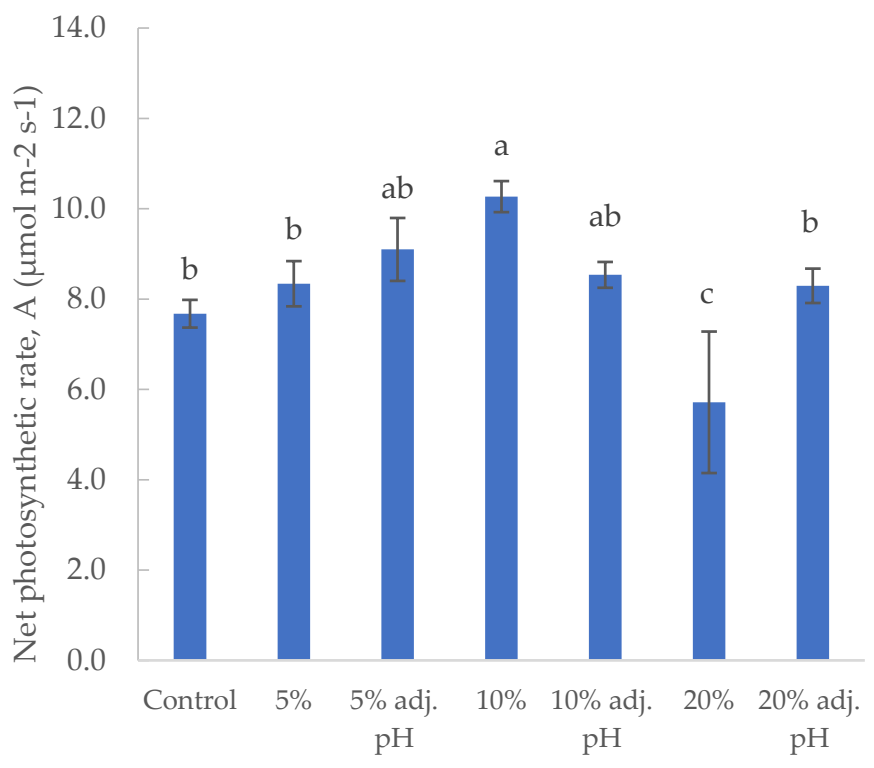

(d)

Figure 4. Photosynthetic parameters $\left(Q_{\text {leaf }}\right.$ : photosynthetic active radiation (a), E: transpiration rate (b), gs: stomatal conductance $(\mathbf{c})$, and A: net photosynthetic rate $(\mathbf{d}))$ of baby lettuce cultivated under different digestate solutions. Columns (means $\pm \mathrm{SE}$ ) with different letters are significantly different $(p<0.05)$.

\subsection{Qualitative Characteristics of Baby Leaf Lettuce}

It is well established that nitrates are noxious to humans, since their action is related to carcinogenic compounds such as nitrosamines [29]. Lettuce is one of the most popular leafy vegetables consumed around the world, but its leaves may contain relatively high amounts of nitrates [27]. In our experiment, nitrate concentrations were significantly greater in lettuce grown in the control tanks compared to all liquid digestate tanks (Figure 5). European Commission Regulation No 1258/2011 states that lettuce produced under cover and harvested between 1 October and 31 March must not exceed $5000 \mathrm{mg}$ nitrates $/ \mathrm{kg}$ fresh weight. In our case, lettuce treated with liquid digestate, regardless of dose and $\mathrm{pH}$ adjustment, accumulated remarkably low amounts of nitrates-125-fold lower than the maximum amount allowed by the European Commission. Remarkably, the concentration of nitrates in lettuce grown in the control tank was also lower than the EU regulations. 
This observation can be attributed to the relatively high solar radiation of $100-300 \mathrm{~W} \mathrm{~m}^{-2}$ reaching the plants inside the greenhouse, since nitrates accumulate in leafy vegetables under low-light conditions due to the reduced activity of nitrate reductase [16].

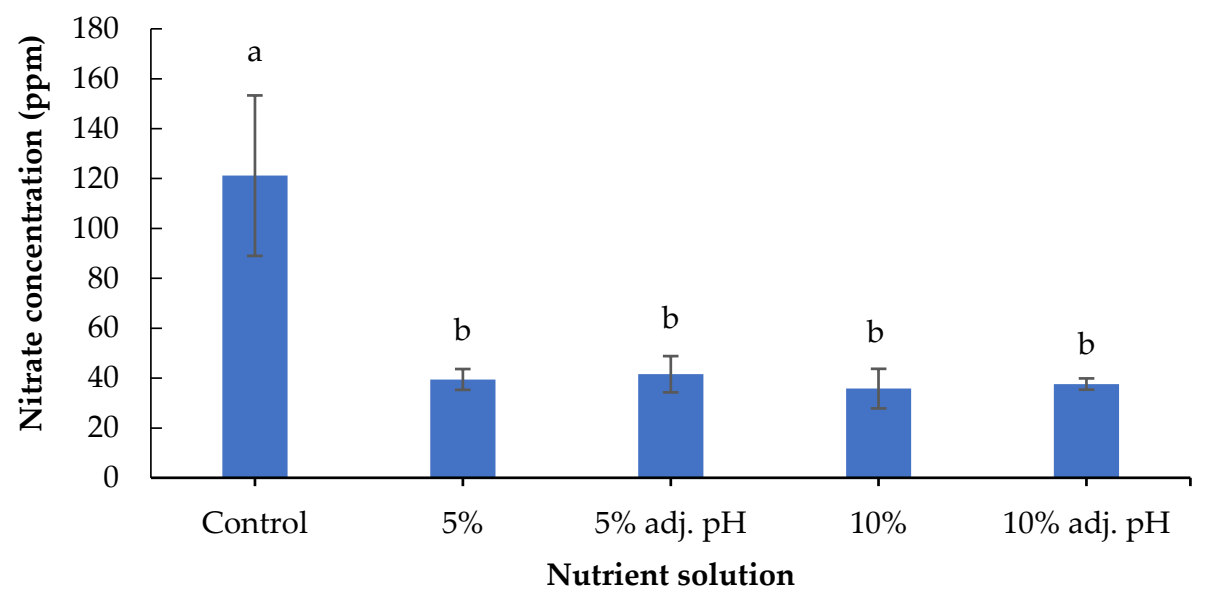

Figure 5. Nitrate content of baby lettuce leaves grown in a floating hydroponic system under different dilutions in water during the winter period. Columns (means $\pm \mathrm{SE}$ ) with different letters are significantly different $(p<0.05)$.

Secondary metabolites including phenolic compounds are produced in response to stress factors, and are involved in plant defense and signaling [30]. The lowest concentration of total phenolics was found in the control treatment, and was significantly lower compared to the treatments in which $10 \%$ digestate was added (with and without $\mathrm{pH}$ adjustment). Furthermore, $10 \%$ liquid digestate also showed significantly greater values compared to $5 \%$ with adjusted $\mathrm{pH}$ (Figure 6). A previous study also demonstrated the beneficial effects of manure-based fertilizers on the phenolic compounds of fruit and vegetable plants compared to conventional farming systems [31]. Leafy vegetables such as lettuce contain several antioxidant compounds that are essential both for a healthy human diet and for the control of oxidative stress in plants [32]. The antioxidant potential displayed by FRAP was significantly enhanced in non-adjusted $5 \%$ and both $10 \%$ liquid digestate treatments compared to the control (Figure 7). These results are consistent with those of a previous study reporting that the application of liquid digestate in 10, 20, or $30 \%$ concentrations enhanced the total phenolic content and DPPH scavenging activity of cucumber compared to the treatment that was grown in non-fertilized soil [33]. These results showcase the positive effects of organic fertilization on the production and accumulation of antioxidant compounds in crops.

A method to evaluate and quantify the taste of leafy vegetables is the determination of soluble sugar content. In a study with tomatoes, the authors reported greater fruit Brix in plants treated with digestate derived from food waste compared with a synthetic fertilizer or no fertilizer [34]. Another study with tomatoes revealed greater Brix content in organically produced fruits compared to conventional systems, while bell peppers in the same study did not show significant Brix differences [31]. In our case, no significant differences were observed in soluble sugar content among the nutrient sources (Figure 8). It must be noted that lettuce grown with $20 \%$ wastewater treatment, either with or without $\mathrm{pH}$ adjustment, did not produce sufficient yield for phytochemical determinations.

\subsection{Mineral Uptake}

The need for increased plant growth via optimal nutrition and the improvement of the nutritional quality of plants as foods sheds light on mineral accumulation in the cultivated plants [35]. Humans require several dietary minerals for health and metabolism [15]; among them, $\mathrm{K}$ is involved in electrolyte balance and various metabolic functions, $\mathrm{Ca}$ and 
$\mathrm{Mg}$ are critical for bone health [36], while iron (Fe) and zinc (Zn) are of particular concern for vegan diets, since vegetables are low in these trace minerals [15].

The determination of nutrient composition in the baby leaf lettuce demonstrates partially efficient mineral uptake by the plants (Table 3), in comparison with the corresponding value of the plants grown in Hoagland solution (control). Specifically, for a group of minerals $(\mathrm{P}, \mathrm{K}, \mathrm{Ca}, \mathrm{Mg}$, and $\mathrm{Fe})$, all digestate treatments had significantly lower concentrations than the control; the reduction was $16-30 \%$ for $\mathrm{P}, 24-44 \%$ for $\mathrm{K}, 8-36 \%$ for $\mathrm{Ca}, 9-24 \%$ for $\mathrm{Mg}$, and $41-69 \%$ for Fe. Conversely, the concentration of Mn was significantly increased by 2.1-4.8-fold compared to the control, and was negatively correlated with the concentration of digestate in the growth medium. Mn is an essential element for the photosynthetic apparatus, as it is involved in the water-splitting reaction in photosystem II [37]. Similarly, significantly higher concentrations of $\mathrm{Zn}$ and $\mathrm{N}$ were observed for all digestate treatments, except for 20 and $5 \%$, respectively. On the other hand, no differences were recorded for $\mathrm{Cu}$ and $\mathrm{B}$ accumulation in baby lettuce leaves.

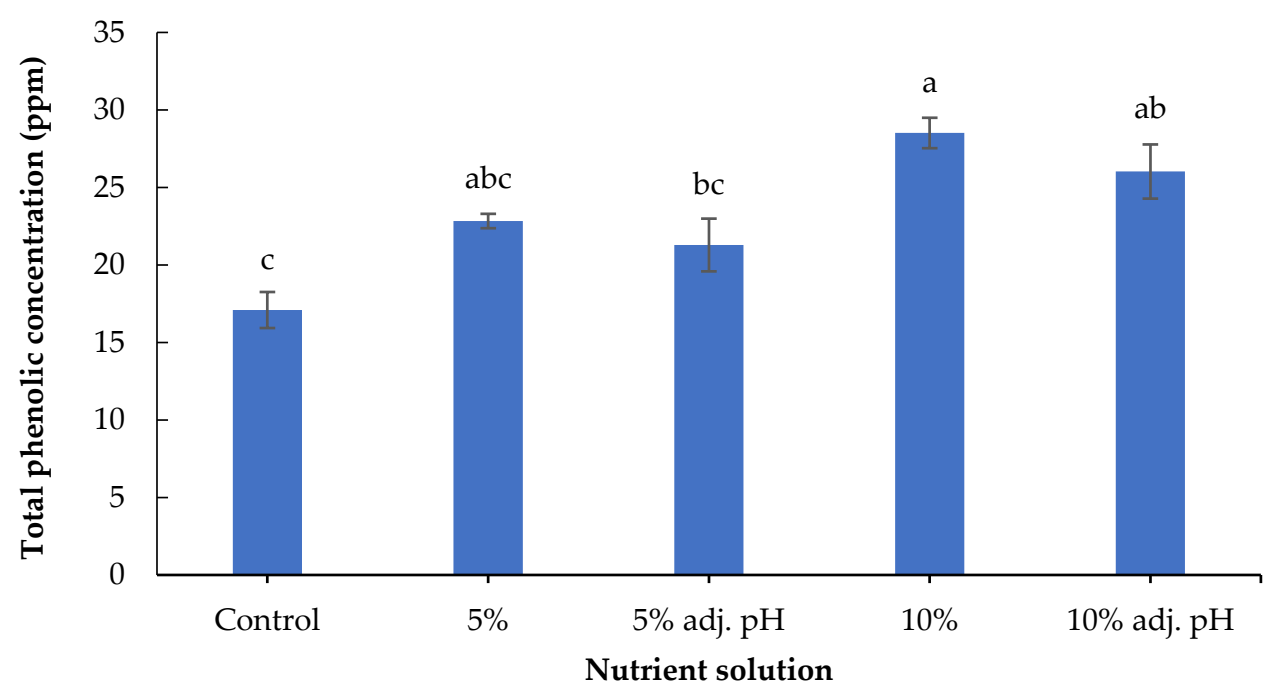

Figure 6. Total phenolics of baby lettuce leaves grown in a floating hydroponic system under different dilutions in water during the winter period. Columns (means $\pm \mathrm{SE}$ ) with different letters are significantly different $(p<0.05)$.

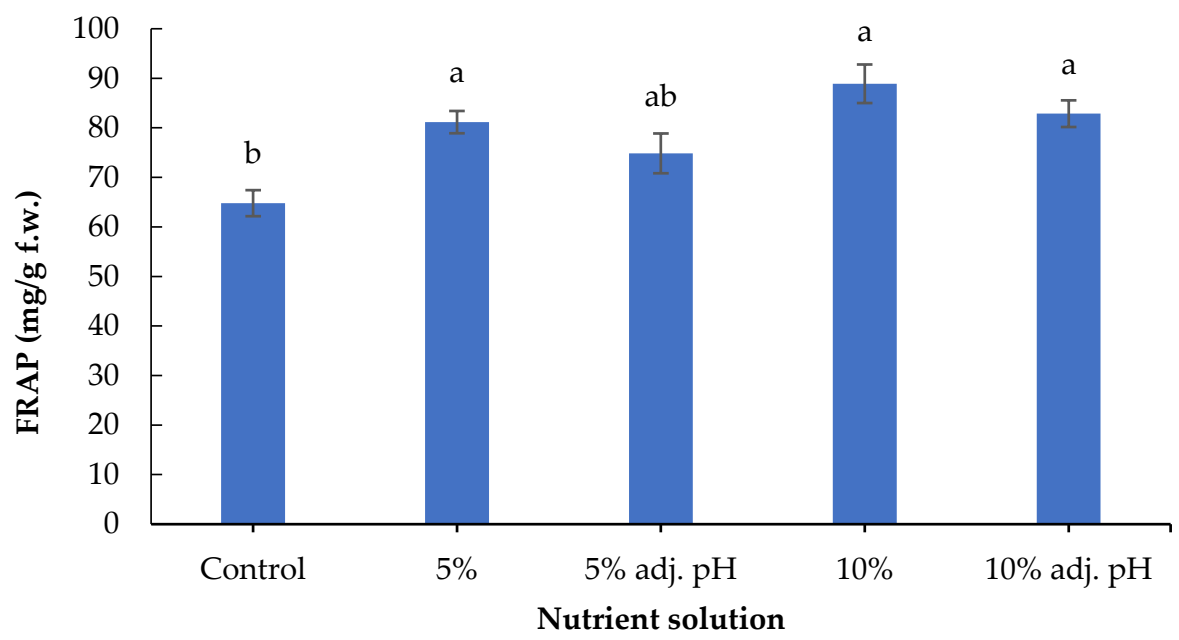

Figure 7. Total antioxidant capacity of baby lettuce leaves grown in a floating hydroponic system under different dilutions in water during the winter period. Columns (means $\pm \mathrm{SE}$ ) with different letters are significantly different $(p<0.05)$. 


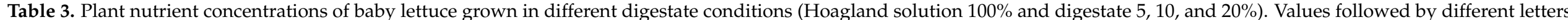
present statistically significant differences $(p<0.05)$.

\begin{tabular}{|c|c|c|c|c|c|c|c|c|c|c|}
\hline & $\mathbf{N}$ & $\mathbf{P}$ & $\mathbf{K}$ & $\mathrm{Ca}$ & Mg & B & Mn & $\mathrm{Zn}$ & $\mathrm{Fe}$ & $\mathrm{Cu}$ \\
\hline Lettuce & $(\%)$ & $(\%)$ & $(\%)$ & $(\%)$ & $(\%)$ & $\left(\mathrm{mg} \mathrm{kg}^{-1}\right)$ & $\left(\mathrm{mg} \mathrm{kg}^{-1}\right)$ & $\left(\mathrm{mg} \mathrm{kg}^{-1}\right)$ & $\left(\mathrm{mg} \mathrm{kg}^{-1}\right)$ & $\left(\mathrm{mg} \mathrm{kg}^{-1}\right)$ \\
\hline Hoagland solution & $5.52 \pm 0.09 \mathrm{e}$ & $2.90 \pm 0.10 \mathrm{a}$ & $9.99 \pm 0.47 a$ & $1.61 \pm 0.17 \mathrm{a}$ & $0.53 \pm 0.01 \mathrm{a}$ & $22.30 \pm 0.90 \mathrm{~d}$ & $48.00 \pm 0.56 \mathrm{f}$ & $36.70 \pm 1.83 \mathrm{~d}$ & $85.70 \pm 2.42 \mathrm{a}$ & $8.01 \pm 0.82 \mathrm{a}$ \\
\hline Digestate $5 \%$ & $5.63 \pm 0.15 \mathrm{e}$ & $2.09 \pm 0.22 c$ & $7.75 \pm 0.70 \mathrm{~b}$ & $1.48 \pm 0.17 \mathrm{~b}$ & $0.48 \pm 0.06 \mathrm{~b}$ & $26.00 \pm 0.29 c$ & $215.00 \pm 21.48 b$ & $64.30 \pm 5.55 b$ & $40.70 \pm 2.31 c$ & $10.39 \pm 3.40 \mathrm{a}$ \\
\hline Digestate $5 \%$ adj $\mathrm{pH}$ & $5.68 \pm 0.13 \mathrm{e}$ & $2.44 \pm 0.07 \mathrm{~b}$ & $7.48 \pm 0.15 \mathrm{~b}$ & $1.42 \pm 0.05 \mathrm{~b}$ & $0.46 \pm 0.01 \mathrm{~b}, \mathrm{c}$ & $27.5 \pm 0.70 \mathrm{~b}$ & $232.00 \pm 14.28 \mathrm{a}$ & $74.7 \pm 9.87 \mathrm{a}$ & $50.10 \pm 4.77 b$ & $7.90 \pm 1.08 \mathrm{a}$ \\
\hline Digestate $10 \%$ & $5.96 \pm 0.05 \mathrm{~d}$ & $1.98 \pm 0.12 \mathrm{c}$ & $7.36 \pm 0.09 b$ & $1.27 \pm 0.07 \mathrm{c}$ & $0.44 \pm 0.03 \mathrm{~b}, \mathrm{c}, \mathrm{d}$ & $20.10 \pm 1.55 \mathrm{~d}, \mathrm{e}$ & $183.00 \pm 12.99 c$ & $60.30 \pm 5.24 b$ & $43.60 \pm 1.61 c$ & $7.33 \pm 3.20 \mathrm{a}$ \\
\hline Digestate $10 \%$ adj $\mathrm{pH}$ & $6.16 \pm 0.10 c$ & $2.40 \pm 0.08 \mathrm{~b}$ & $6.70 \pm 0.32 c$ & $1.19 \pm 0.07 \mathrm{c}, \mathrm{d}$ & $0.41 \pm 0.03 \mathrm{~d}$ & $30.50 \pm 3.51 \mathrm{a}$ & $202.00 \pm 4.70 \mathrm{~b}$ & $73.30 \pm 11.01 \mathrm{a}$ & $49.40 \pm 2.87 \mathrm{~b}$ & $8.95 \pm 0.80 \mathrm{a}$ \\
\hline Digestate $20 \%$ & $6.88 \pm 0.08 \mathrm{a}$ & $1.53 \pm 0.09 \mathrm{~b}$ & $5.61 \pm 0.27 \mathrm{~d}$ & $1.02 \pm 0.09 \mathrm{e}$ & $0.40 \pm 0.04 \mathrm{~d}$ & $15.10 \pm 1.01 \mathrm{f}$ & $103.00 \pm 8.90 \mathrm{e}$ & $41.30 \pm 1.86 \mathrm{~d}$ & $26.30 \pm 5.29 \mathrm{~d}$ & $6.18 \pm 0.89 a$ \\
\hline Digestate $20 \%$ adj $\mathrm{pH}$ & $6.59 \pm 0.32 \mathrm{~b}$ & $2.07 \pm 0.26 \mathrm{c}$ & $6.32 \pm 0.36 c$ & $1.08 \pm 0.07 \mathrm{~d}, \mathrm{e}$ & $0.42 \pm 0.04 \mathrm{~cd}$ & $19.80 \pm 2.62 \mathrm{e}$ & $128.00 \pm 15.43 \mathrm{~d}$ & $51.60 \pm 4.53 c$ & $41.40 \pm 6.33 c$ & $8.18 \pm 0.65 a$ \\
\hline
\end{tabular}




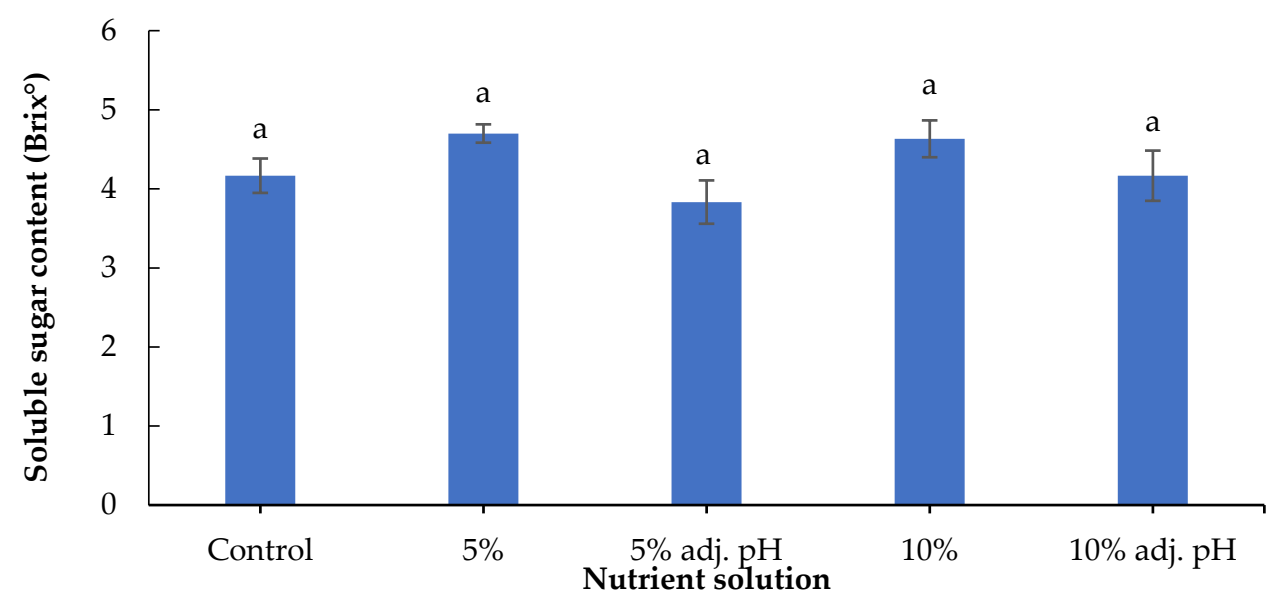

Figure 8. Soluble sugar content $\left(\right.$ Brix $\left.^{\circ}\right)$ of baby lettuce leaves grown in a floating hydroponic system under different dilutions in water during the winter period. Columns (means $\pm \mathrm{SE}$ ) with different letters are significantly different $(p<0.05)$.

The reductions in nutrient concentrations in the growth media with the above results demonstrate adequate mineral uptake by the plants (Figure 9). Specifically, the concentrations of all elements in the growth media (except for $\mathrm{Na}$ in the treatments in which $5 \%$ digestate was added) decreased throughout the cultivation period. Conversely, the increase in Na concentration in the treatment that included 5\% digestate could be attributed to low uptake by the plant, and subsequent accumulation in the root zone. It has previously been reported that $\mathrm{Na}$ interferes with other elements, such as $\mathrm{Ca}$ and $\mathrm{Mg}$, which often leads to plant disorders [38]. Further studies are required in order to study the interaction between mineral concentrations in the growth media and their accumulation in plant tissues.

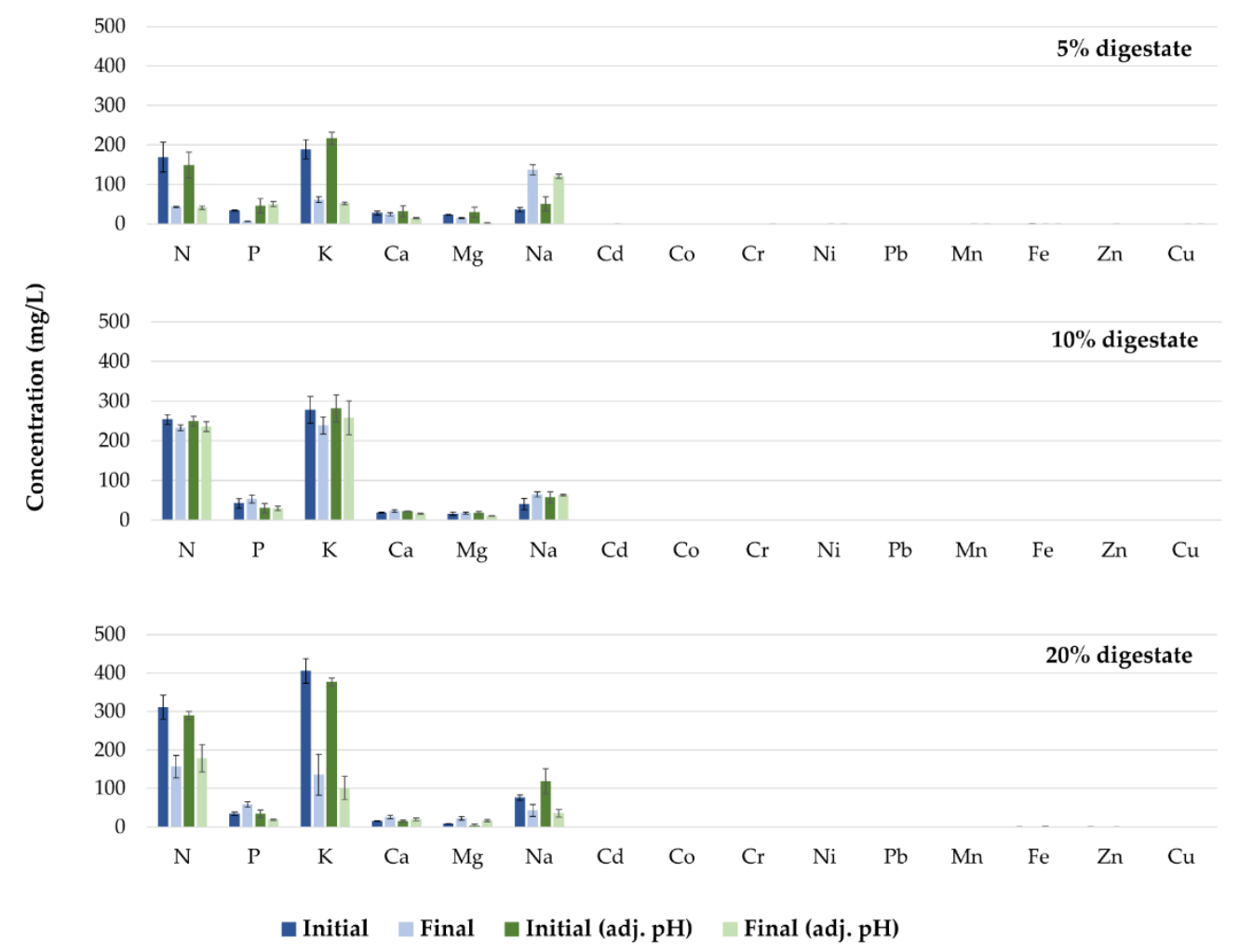

Figure 9. Concentrations of nutrients in the different growth media prior to (Initial), and at the end of (Final), the cultivation period. 


\section{Conclusions}

The present study demonstrates an efficient application of liquid digestate as a fertilizer for the hydroponic cultivation of baby lettuce grown in a greenhouse using a floating system. Specifically, even though the plant growth was affected by the increased digestate concentration, the qualitative characteristics of the baby leaf lettuce demonstrated enhanced antioxidant capacity and efficient production of secondary metabolites. Moreover, the reductions in nutrient concentrations in the growth media demonstrated enhanced residual resource recovery, suggesting that the exploitation of digestate can partially replace some inorganic fertilizers. For this reason, the current exploitation of liquid digestate can be envisaged as a promising method to recycle and upcycle nutrients and carbon within greenhouses, reducing the environmental footprint of the end products. Thus, this agronomic practice offers unique opportunities for the achievement of a more sustainable and environmentally friendly food production, creating synergies between the agricultural and bioenergy sectors. As such, the agricultural residues from greenhouses can serve as influent feedstock for biogas plants, while the obtained digestate can be used as a nutrient supplement for greenhouse crops. Based on the outcomes of the present work, the microbial impact on stimulating plant growth-and particularly the potential colonization of microbes in the root endosphere and rhizosphere-might provide essential information for further optimization of current farming systems. Finally, it would be beneficial to evaluate the impact of digestate as the sole or partial nutrient source in other greenhouse crops to reduce their carbon footprint.

Author Contributions: Conceptualization, G.K.N., P.G.K. and A.K.; methodology, G.K.N., P.G.K. and A.K.; investigation, G.K.N. and P.G.K.; data curation, G.K.N., P.G.K., F.B. and A.K.; writing-original draft preparation, G.K.N., P.G.K. and F.B.; writing-review and editing, G.K.N., P.G.K. and A.K. All authors have read and agreed to the published version of the manuscript.

Funding: This research was funded by Rural Development Program (RDP) 2014-2020, Sub-measure 19.2-Support for the implementation of actions of the Local Development Strategies initiated by the Local Communities (CLLD/LEADER), grant number LD181-0053369-bioFERTIL-Promoting the use of stabilized residue from biogas plants as an innovative soil conditioner.

Institutional Review Board Statement: Not applicable.

Informed Consent Statement: Not applicable.

Data Availability Statement: Not applicable.

Conflicts of Interest: The authors declare no conflict of interest.

\section{References}

1. Kougias, P.G.; Angelidaki, I. Biogas and its opportunities-A review. Front. Environ. Sci. Eng. 2018, 12, 14. [CrossRef]

2. Alibardi, L.; Green, K.; Favaro, L.; Vale, P.; Soares, A.; Cartmell, E.; Fernández, Y.B. Performance and stability of sewage sludge digestion under $\mathrm{CO}_{2}$ enrichment: A pilot study. Bioresour. Technol. 2017, 245, 581-589. [CrossRef]

3. Möller, K.; Müller, T. Effects of anaerobic digestion on digestate nutrient availability and crop growth: A review. Eng. Life Sci. 2012, 12, 242-257. [CrossRef]

4. Duan, N.; Khoshnevisan, B.; Lin, C.; Liu, Z.; Liu, H. Life cycle assessment of anaerobic digestion of pig manure coupled with different digestate treatment technologies. Environ. Int. 2020, 137, 105522. [CrossRef]

5. Drosg, B.; Fuchs, W.; Al Seadi, T.; Madsen, M.; Linke, B. Nutrient Recovery by Biogas Digestate Processing; IEA Bioenergy: Dublin, Ireland, 2015; p. 711.

6. Estevez, M.M.; Sapci, Z.; Linjordet, R.; Schnürer, A.; Morken, J. Semi-continuous anaerobic co-digestion of cow manure and steam-exploded Salix with recirculation of liquid digestate. J. Environ. Manag. 2014, 136, 9-15. [CrossRef]

7. Barłóg, P.; Hlisnikovský, L.; Kunzová, E. Effect of digestate on soil organic carbon and plant-available nutrient content compared to cattle slurry and mineral fertilization. Agronomy 2020, 10, 379. [CrossRef]

8. Xia, A.; Murphy, J.D. Microalgal cultivation in treating liquid digestate from biogas systems. Trends Biotechnol. 2016, 34, 264-275. [CrossRef] [PubMed]

9. Maucieri, C.; Nicoletto, C.; Van Os, E.; Anseeuw, D.; Van Havermaet, R.; Junge, R. Hydroponic technologies. In Aquaponics Food Production Systems; Springer: Cham, Switzerland, 2019; pp. 77-110. 
10. Nicola, S.; Hoeberechts, J.; Fontana, E. Comparison between traditional and soilless culture systems to produce rocket (Eruca sativa) with low nitrate content. Acta Hortic. 2005, 697, 549-555. [CrossRef]

11. Karnoutsos, P.; Karagiovanidis, M.; Bantis, F.; Chatzistathis, T.; Koukounaras, A.; Ntinas, G.K. Controlled root-zone temperature effect on baby leaf vegetables yield and quality in a floating system under mild and extreme weather conditions. J. Sci. Food Agric. 2019, 101, 3933-3941. [CrossRef]

12. Kotsiras, A.; Vlachodimitropoulou, A.; Gerakaris, A.; Bakas, N.; Darras, A.I. Innovative harvest practices of Butterhead, Lollo rosso and Batavia green lettuce (Lactuca sativa L.) types grown in floating hydroponic system to maintain the quality and improve storability. Sci. Hortic. 2016, 201, 1-9. [CrossRef]

13. Conesa, E.; Niñirola, D.; Vicente, M.J.; Ochoa, J.; Bañón, S.; Fernández, J.A. The influence of nitrate/ammonium ratio on yield quality and nitrate, oxalate and vitamin c content of baby leaf spinach and bladder campion plants grown in a floating system. Acta Hortic. 2009, 843, 269-274. [CrossRef]

14. Hoagland, D.R.; Arnon, D.I. The Water-Culture Method for Growing Plants without Soil. Circ. Calif. Agric. Exp. Stn. 1950, 347, 32. Available online: https://scholar.google.com/scholar_lookup?title=The+Water-Culture+Method+for+Growing + Plants+ without+Soil\&author=Hoagland,+D.R.\&author=Arnon,+D.I.\&publication_year=1950 (accessed on 8 July 2021).

15. Kim, M.J.; Moon, Y.; Tou, J.C.; Mou, B.; Waterland, N.L. Nutritional value, bioactive compounds and health benefits of lettuce (Lactuca sativa L.). J. Food Compos. Analys. 2016, 49, 19-34. [CrossRef]

16. Santamaria, P. Nitrate in vegetables: Toxicity, content, intake and EC regulation. J. Sci. Food Agric. 2006, 86, 10-17. [CrossRef]

17. Colla, G.; Kim, H.J.; Kyriacou, M.C.; Rouphael, Y. Nitrate in fruits and vegetables. Sci. Hortic. 2018, 237, 221-238. [CrossRef]

18. Stoknes, K.; Scholwin, F.; Krzesiński, W.; Wojciechowska, E.; Jasińska, A. Efficiency of a novel "Food to waste to food" system including anaerobic digestion of food waste and cultivation of vegetables on digestate in a bubble-insulated greenhouse. Waste Manag. 2016, 56, 466-476. [CrossRef]

19. Ronga, D.; Pellati, F.; Brighenti, V.; Laudicella, K.; Laviano, L.; Fedailaine, M.; Benvenuti, S.; Pecchioni, N.; Francia, E. Testing the influence of digestate from biogas on growth and volatile compounds of basil (Ocimum basilicum L.) and peppermint (Mentha $x$ piperita L.) in hydroponics. J. Appl. Res. Medic. Arom. Plants 2018, 11, 18-26. [CrossRef]

20. Ronga, D.; Setti, L.; Salvarani, C.; De Leo, R.; Bedin, E.; Pulvirenti, A.; Milc, J.; Pecchioni, N.; Francia, E. Effects of solid and liquid digestate for hydroponic baby leaf lettuce (Lactuca sativa L.) cultivation. Sci. Hortic. 2019, 244, 172-181. [CrossRef]

21. Cataldo, D.A.; Haroon, M.H.; Schrader, L.E.; Youngs, V.L. Rapid colorimetric determination of nitrate in plant tissue by nitration of salicylic acid. Commun. Soil Sci. Plant Anal. 1975, 6, 71-80. [CrossRef]

22. Singleton, V.L.; Rossi, J.A. Colorimetry of total phenolics with phosphomolybdic-phosphotungstic acid reagents. Am. J. Enol. Vitic. 1965, 16, 144-158.

23. Benzie, I.F.F.; Strain, J.J. The ferric reducing ability of plasma (FRAP) as a measure of 'antioxidant power': The FRAP assay. Anal Biochem. 1996, 239, 70-76. [CrossRef]

24. Watanabe, F.S.; Olsen, S.R. Test of an ascorbic acid method for determining phosphorus in water and $\mathrm{NaHCO}_{3}$ extracts from soil. Soil Sci. Soc. Am. J. 1965, 29, 677-678. [CrossRef]

25. Aschonitis, V.; Karydas, C.G.; Iatrou, M.; Mourelatos, S.; Metaxa, I.; Tziachris, P.; Iatrou, G. An integrated approach to assessing the soil quality and nutritional status of large and long-term cultivated rice agro-ecosystems. Agriculture 2019, 9, 80. [CrossRef]

26. Gonnella, M.; Serio, F.; Conversa, G.; Santamaria, P. Yield and quality of lettuce grown in floating system using different sowing density and plant spatial arrangements. In Proceedings of the VI International Symposium on Protected Cultivation in Mild Winter Climate: Product and Process Innovation, Ragusa-Sicilia, Italy, 5-8 March 2002; Volume 614, pp. 687-692.

27. Wenceslau, D.D.S.L.; de Oliveira, D.F.; de Oliveira Rabelo, H.; Ferbonink, G.F.; Gomes, L.A.A.; Leonel, E.C.A.; Caione, G. Nitrate concentration and nitrate/ammonium ratio on lettuce grown in hydroponics in Southern Amazon. Afr. J. Agric. Res. 2021, $17,862-868$.

28. Celletti, S.; Lanz, M.; Bergamo, A.; Benedetti, V.; Basso, D.; Baratieri, M.; Cesco, S.; Mimmo, T. Evaluating the Aqueous Phase from Hydrothermal Carbonization of Cow Manure Digestate as Possible Fertilizer Solution for Plant Growth. Front. Plant Sci. 2021, 12, 687434. [CrossRef]

29. Chung, J.-B.; Jin, S.-J.; Cho, H.-J. Low water potential in saline soils enhances nitrate accumulation of lettuce. Commun. Soil Sci. Plant Analys. 2007, 36, 1773-1785. [CrossRef]

30. Lattanzio, V.; Lattanzio, V.M.T.; Cardinali, A. Role of phenolics in the resistance mechanisms of plants against fungal pathogens and insects. In Phytochemistry: Advances in Research; Imperato, F., Ed.; Research Signpost: Trivandrum, India, 2006 ; pp. $23-67$.

31. Chassy, A.W.; Bui, L.; Renaud, E.N.C.; Van Horn, M.; Mitchell, A.E. Three-Year Comparison of the Content of Antioxidant Microconstituents and Several Quality Characteristics in Organic and Conventionally Managed Tomatoes and Bell Peppers. J. Agric. Food. Chem. 2006, 54, 8244-8252. [CrossRef]

32. Ostan, R.; Lanzarini, C.; Pini, E.; Scurti, M.; Vianello, D.; Bertarelli, C.; Fabbri, C.; Izzi, M.; Palmas, G.; Biondi, F.; et al. Inflammaging and cancer: A challenge for the Mediterranean diet. Nutrients 2015, 7, 2589-2621. [CrossRef] [PubMed]

33. Panuccio, M.R.; Papalia, T.; Attinà, E.; Giuffrè, A.; Muscolo, A. Use of digestate as an alternative to mineral fertilizer: Effects on growth and crop quality. Arch. Agron. Soil Sci. 2019, 65, 700-711. [CrossRef]

34. Barzee, T.J.; Edalati, A.; El-Mashad, H.; Wang, D.; Scow, K.; Zhang, R. Digestate Biofertilizers Support Similar or Higher Tomato Yields and Quality Than Mineral Fertilizer in a Subsurface Drip Fertigation System. Front. Sustain. Food Syst. $2019,3,58$. [CrossRef] 
35. Martínez-Ballesta, M.C.; Dominguez-Perles, R.; Moreno, D.A.; Muries, B.; Alcaraz-López, C.; Bastías, E.; García-Viguera, C.; Carvajal, M. Minerals in plant food: Effect of agricultural practices and role in human health. A review Agron. Sustain. Dev. 2010, 30, 295-309. [CrossRef]

36. Soetan, K.O.; Olaiya, C.O.; Oyewole, O.E. The importance of mineral elements for humans, domestic animals and plants: A review. Afr. J. Food Sci. 2010, 45, 200-222.

37. Alejandro, S.; Holler, S.; Meier, B.; Peiter, E. Manganese in Plants: From Acquisition to Subcellular Allocation. Front. Plant Sci. 2020, 11, 300. [CrossRef] [PubMed]

38. Van Os, E.A.; Blok, C.; Voogt, W.; Waked, L. Water quality and salinity aspects in hydroponic cultivation. WUR Glastuinbouw 2016, 1-7. Available online: https:/ / edepot.wur.nl/403810 (accessed on 18 July 2021). 